\title{
The Effect of Javanese Language Philosophical Aspect on the Society's Communication Pattern in Indonesian Language
}

\author{
Tri Wahyono, M.Pd. ${ }^{1}$ \\ Mechanical Engineering Department, Faculty of Engineering \\ Universitas Muhammadiyah Yogyakarta \\ Jl. Lingkar Selatan, Tamantirto, Kasihan, Bantul, Yogyakarta, \\ Yogyakarta, Indonesia \\ wahyonotri25@gmail.com
}

\author{
Toriq Pratama, M.Pd. ${ }^{2}$ \\ Language Trainning Center \\ Universitas Muhammadiyah Yogyakarta \\ Jl. Lingkar Selatan, Tamantirto, Kasihan, Bantul, \\ Yogyakarta, Indonesia \\ toriqpratama2016@gmail.com
}

\begin{abstract}
The pattern of communication in the Indonesian language in society is beginning to ignore the aspect of respect for the hearers. This paper aims to determine the effects of understanding the philosophical aspects of Java language to the pattern of society communication in the Indonesian language. Descriptive data obtained in this paper through observation and theoretical study of the language phenomenon and communication patterns in society. The analysis process is done theoretically and descriptively and through the process of language comparison. The results show that understanding the meaning of Javanese philosophy influenced the communication pattern of the people in using the Indonesian language in terms of words or phrases and words. The influence of the meaning of the philosophy comes in the form of changes in the word meaning and the mention pronouns in communicating.
\end{abstract}

Keywords- aspects of Javanese philosophy; communication patterns

\section{INTRODUCTION}

Language is a primary means of communication so that the language understanding is very significant in society life. In the daily life, language plays an important role in every life aspects. Trough a language, someone can convey his intention so that the information and message for society are received well. The information and message have to be delivered in the appropiate language, so the meaning can be understood by receiver easily because the difficulty in understanding some information and message can make different interpretation and understanding.

Based on that condition language can be a way to express someones ideas and minds. Through the clear language and expression, information and message can be comprehended and translated easily by the receivers. Moreover, someone's expression in giving information and message can cause different levels of understanding towards the receivers. This is so because someone expression in giving a message is influenced by his cultural social and society background. Consequently, the cultural condition of Indonesian language speakers highly affects the way they express information or message.

The diverse culture of the society influences the communication pattern in the society. That pattern can be found in the forms of idiom, language terms, or words in certain culture which are brought when communicating in Indonesian language. Sometimes, culture plays a dominant rule in someone's communication pattern in the society so that some unexpressed condition in Indonesian language have to be shown in the regional language expression. In this case, the writers will describe some idioms, terms, and words in Javanese language which are use in Indonesian language to express and deliver messages because they are considered to have philosopical values which can be understood commonly by the society.

Those Javanese words are used to express and ilustrate the various condition in the society recently. Those conditions are social, cultural, political, economic, law, education, and religion conditions. Those conditions sometimes can be more easily expressed in Javanese language because the meanings are easier to be understood. That language phenomenon happens because of the lack of languages media in Indonesian language which can describe the condition of Indonesian society and government. Therefore, the condition becomes one of the reasons why various terms and communication pattern in Indonesian language which are influenced by the Javanese language philosophy exist.

This paper is aimed at finding the influence of terms and words with Javanese language phylosopy on Indonesian language. The writers expect this paper can give understanding and knowledge for the writers and the readers on the Indonesian language development. Furthermore, this paper can give insight that a language will always develop dynamically to fit the speakers and societies condition and cultural background.

\section{RESEARCH METHOD}

The research method used in this paper was done through observation and analysis of phenomenon of language in 
society, as well as theoretical study (literature study) on the origin of the Indonesian language. In the analysis process, the author uses theoretical references to the development of Indonesian language in communicating activities in the community derived from the Javanese language philosophy. The words absorbed from the Javanese language can be terms or phrases, stem words, and pronouns.

\section{DISCUSSION}

The philosophical aspect becomes an interesing topic to discuss when it is related to communication and culture. Arnett [1] states that communication philosophy in term of the language understanding as a communicative means of commmunication, has to give clear understanding both for the speakers and listeners. It means, language philosophy has to be completely understood as a verbal means of communication. The big numbers of Javanese words or terms containing the philosopical meaning which can be easily understood causes the language absorption process in Indonesian language can be received easily as well. Based on those language real function, the relationship between language and philosophy is closely related and even inseparable [2]. Philosophically, the review in this paper is an ontological review which discusses real scientific studies and analysis which the result can be measured and estimated [3].

1. The Philosophical Javanese Word which are Absorbed by Indonesian Language

a. Pronouns

Recently there are many Javanese word which are absorbed in Indonesian language with some reasons. Those process happen because of the lack of Indonesian vocabulary to state objects or condition. Otherwise, in Javanese language there are many words which can be used to state an object so that Indonesian language speakers with Javanese cultural background can easily use those word. Based on that process there are many Javanese words which are absorbed into Indonesian language to meet the need of vocabulary completeness. According to Maneechukate [4] one of the mean intentions of word absorbtion is to complete a word and its use. That process is conducted through word borrowing coming some factors such as the influence of trade, religion, culture, and technology development.

Based on development, Indonesian language consists of various absorbed words from other languages. In this case Javanese language is one of the sources. However, the absorption process not only caused by the need of the vocabulary but also because of the phylosopical meaning factor in Javanese language. The Javanese words meaning philosophy is influenced by the language manners (unggahungguhing basa).

According to Rahmawati [5], the Javanese can use Javanese language in their daily life because they often use the language in their daily life. Their parents accustom them to use Javanese language for communication since they are young. Then those repetitive actions sooner or later become a habit.

The awareness in using Javanese language affects someone to integrate cultural aspects in using the language. Javanese culture which highly honours each other causes language expressions produce various word class with changing meanings. As we know that the changing of words meaning in Indonesian language can be meaning expansion, constriction, ameliorative, and pejorative. In this case, the changing word meanings influenced by Javanese culture with phylosopical meaning are ameliorative and pejorative. Ameliorative meaning is the changing of the words meaning to be better from the previous ones. For example the word 'perempuan' becomes 'wanita' and 'laki-laki' becomes 'pria'. Pejorative meaning is the changing of the words meaning to be worse or more rude from the previous ones. For example the word 'istri' becomes 'bini', 'hamil' becomes 'bunting', and 'meninggal' becomes 'mati'.

Beside the changing of the word meaning, Javanese culture influences the subject and object pronouns. The examples are as follows :

- $a k u$, saya $(\mathrm{I})$

- kamu, anda,(you) saudara, bapak/ibu (Sir/ Ma'am), dia/ia, beliau (he / she)

The differences in terms of pronouns and meaning change are intended to honour the addressee so that the communication process seems to be more polite or rude depends on the addressee's condition. From that explanation, a communication process must be based on the communication ethics to keep the freedom in responsibly expressing ideas.

Since there are various concepts in communicating, according to Robillard [6] communication and information become closely interrelated. Communication concept does not only refer to the speaker's and listener's conceptual meaning but also in a social scope, philosophical theory on reality, and the social life righteousness.

\section{b. Stem Words}

There are some Indonesian stem words which come from Javanese language absorption.

For example:

1. $\operatorname{gampang}($ Javanese $)=\operatorname{mudah}($ Indonesian $)=$ easy sentence : Mendidik anak bukan perkara gampang bagi orang tua zaman sekarang. It's not easy for the parents to bring up their children nowadays.

\section{2. $\operatorname{rampung}(\mathrm{J})=$ selesai $(\mathrm{I})=$ finish}

sentence : Gol dari pemain pengganti tim tamu sebelum pertandingan rampung membuyarkan kemenangan tim tuan rumah. The goal stroke by the guest substitute player before the match fnished destroy the host team victory. 
3. $\operatorname{ngomong}(\mathrm{J})=$ bicara $(\mathrm{I})=$ speak

sentence : Jika tak memiliki keberanian ngomong di depan khalayak, akan selamanya grogi karena tak pernah mencoba

If you don't dare to speak in public, you will be nervous forever because you have never tried.

4. $\operatorname{joget}(\mathrm{J})=$ menari $(\mathrm{I})=$ dance

sentence : Penonton ikut bernyanyi dan joget diiringi lagu dangdut yang dinyanyikan penyanyi populer. The audiences sing and dance accompanied by dangdut music sung by a popular singer.

5. doyan $(\mathrm{J})=$ gemar, suka $(\mathrm{I})=$ like

sentence : Banyak mahasiswa yang doyan ke kampus tanpa mengenakan helm, padahal hal ini berbahaya.

There are many students who like to go to the college without wearing the helmets eventhough it is dangerous.

Javanese language is a regional language which develops particularly in Java island. This language supports the existence as well as enriches Indonesian language. This is shown in the existence of Javanese word forms which are absorbed by Indonesian language. Muhadjir [7] states that Javanese language becomes the source to fulfill the less formal communication requirements such as journalistics language development and daily small talks as mentioned before.

\section{Javanese Terms/ Idioms which are Absorbed by Indonesian Language}

Some Indonesian terms to describe certain conditions are absorbed from Javanese language. This is because Javanese language possesses abundant phylosophical meanings and values. In Javanese language, those terms are used as a means to express ideas or deliver messages to be received and understood easily by the receivers. Hariwijaya [8] divides those terms into four categories, those are a) sesanti kabudayan jawa, b) pasemon dan tradisi, c) sanepa mawa tengara, dan d) piwulang kautaman. The categories can be explained as follows:

\section{a. Sesanti Kabudayan Jawa}

Sesanti is a slogan used to encourage, motivate, increase self-confidence, build unconscious power, and strengthen a group unity and solidarity. As a slogan, sesanti sentence is energize, compact and meaningful with beautiful and memorable language. In this society modern life, sesanti as well as slogan or motto legally becomes slogans of many regions in Indonesia. It is also used as Indonesian national slogan. The followings are some sesanti which are widely known in Indonesian language,

1. Bhinneka tunggal ika, means unity in diversity.
2. Tut wuri handayani, means a leader who gives support from behind.

3. Ing ngarsa sung tuladha, means a leader who gives examples in front of his people.

4. Ing madya mangun karsa, means a leader motivates their people.

Those sesanti are used by the nation as slogans for their constitutional life.

\section{b. Pasemon and Tradisi}

Pasemon is a polite satire addressed to the people having high positions in the country about the governance condition in Javanese society. That term appears because of the Javanese social regulation which hierarchically produces word classes. In Javanese, word classes are called unggahungguhing basa or the manners in using the language. Pasemon is used to give opinions or criticize the seniors with a polite language since a carelessness in stating social criticisms can endanger someone's life.

There are some pasemon used in Indonesian language as follows,

1. cicak versus buaya, artinya petugas atau pejabat kelas bawah yang akan menangkap pejabat tinggi yang bermasalah (house lizard vs crocodile means the low level officer who will arrest guilty high positioned people)

2. tikus kantor, artinya kritik atau sebutan untuk pejabat pemerintah yang melakukan korupsi atau pencurian uang negara berkedok petugas negara. (office mouse means corrupt officers)

Pasemon is frequently used as a statement to express citizens' criticisms towards the government.

\section{c. Sanepa Mawa Tengara}

Sanepa is a Javanese polite satire to criticize others without offending those people since they are forced to understand the meaning of the satire themselves. In Indonesian language, it is called 'ironi'. There are some sanepa used in Indonesian language as follows,

1. Pait madu eseme, artinya senyumnya sepahit madu (his smile as bitter as honey)

2. Landep dhengkul pikirane, artinya pikirannya lebih tajam dari lutut (his mind is sharper than knee)

Sanepa is frequently used as a satire for other people in a certain condition which cannot be expressed in a complete language.

\section{d. Piwulang Kautaman}

Piwulang is an advise given to someone in a good matter. It is used to teach people to do good things each other. It is an effort to sharpen someone's ability to always behave properly to other because humans naturally have the ability to decide which one is right or wrong, good or bad. There are some piwulang kautaman used in Indonesian language as follows,

1. Adi luhung, means the noble value 
2. Aji mumpung, ilmu mumpung means abusing opportunities to personal gain

3. Alon-alon waton klakon, means slowly executed

4. Bobot, bibit, bebet, means intelligence, ancestry, and wealth

5. Darma bakti, means dedication

6. Digdaya tanpa aji, means powerful without weapons

7. Guru swadaya, means autodidact

8. Kadalu warsa, means expired

9. Mawas diri, means introspection

10. Ngelmu kasampurnan, means the science that makes a person's life perfect

11. Salah kaprah, means wrong expressions or conditions but already understood together

12. Sakti mandraguna, means powerful person

13. Sim salabim, means magic spell

14. Tumpeng sari, means planting in one field, (Hariwijaya, 2013).

Piwulang kautaman is often used to give information or messages as an advise to teach good behavior in the society life.

\section{CONCLUSIONS}

This paper explains that someone's understanding on Javanese language philosopical meanings affects the society communication pattern in the forms of terms, stem words, and pronouns in Indonesian language. Based on that result, it is expected to enhance the understanding of the words meanings in communication to increase someone's self-confidence in communicating with other people both in the same and higher positions.

(The original version of this journal has been published in Journal 'Analisis' of State University of Jakarta Vol. 12, June 2016).

\section{REFERENCES}

[1] Arnett, Ronald C. "Defining Philosophy of Communication Difference and Identify". Journal Qualitative Research Reports in Communication, Vol. 11, No.1, 2010 pp.57-62.

[2] Kaelan. 2009. Filsafat Bahasa Semiotika dan Hermeneutika. Yogyakarta: Paradigma.

[3] Djojosuroto, Kinayati dan M.L.A. Sumaryati. 2014. Bahasa dan Sastra (Penelitian, Analisis, dan Pedoman Apresiasi). Bandung: Nuansa Cendekia.

[4] Maneechukate, S. 2014. Jurnal Kependidikan. Kata Serapan Bahasa Sanskerta dalam Bahasa Indonesia dan Bahasa Thai sebagai Bahan Pengajaran Bahasa. Volume 44, Nomor 2, November 2014, Halaman 158-167. Thailand: Faculty of Liberal Arts, Maejo University.

[5] Rahmawati, Oktavia. 2014. "Pengaruh Kebiasaan Berbahsa Jawa di Rumah Terhadap Pemahaman Konsep Bahasa Jawa Siswa Kelas V SDIT NUR HIDAYAH Surakarta Tahun Pelajaran 20132014." Naskah Publikasi. Fakultas Keguruan dan Ilmu Pendidikan, Universitas Muhammadiyah Surakarta.

[6] Robillard, Jean. 2005. "Philosophy of communication: What Does It Have to Do with Philosophy of Social Sciences". The Journal of Natural and Social Philosophy, Vol. 1, no. 2.
[7] Muhadjir. 1998. "Kecenderungan Baru Perkembangan Kosakata dan Sistem Pembentukan Kata Bahasa Indonesia”, Pertemuan Linguistik Bahasa dan Budaya Atma Jaya Kedua belas. Jakarta: Unika Atma Jaya.

[8] Hariwijaya, M. 2013. Semiotika Jawa Kajian Makna Falsafah Tradisi. Yogyakarta: Paradigma.

[9] Haryatmoko. 2007. Etika Komunikasi (Manipulasi Media, Kekerasan, dan Pornografi). Yogyakarta: Kanisius. 
